\title{
Studies on pollen sources for Apis cerana Fabr and Apis mellifera $L$ bees at Muzaffarpur, Bihar, India
}

\author{
MC Suryanarayana *, G Mohana Rao, TSMS Singh \\ Khadi and Village Industries Commission, Central Bee Research and Training Institute, \\ 1153 Ganeshkhind Road, Pune 411016, India
}

(Received 6 May 1991; accepted 23 August 1991)

\begin{abstract}
Summary - At Muzaffarpur, Bihar, in northern India, a total of 40 and 48 plant species served as pollen sources to Apis cerana Fabr and $A$ mellifera $L$ respectively. The major, medium and minor pollen sources were identified. The peak in pollen availability was observed from January to May and again in November. The dearth period was July-August in this area. The main differences in pollen foraging between 2 honey bee species were noted. Each of the species had 13 anemophilous plant species as sources of pollen.
\end{abstract}

Apis mellifera / Apis cerana / pollen plant / foraging / India

\section{INTRODUCTION}

Microscopic analysis of pollen loads collected by foragers of a honey bee colony has been an established melittopalynological method to determine the sources of pollen for bee colonies. As early as 1908, Betts (1935) initiated investigations of pollen loads from Apis mellifera $L$ bee colonies in England, to determine the pollen plants and to identify factors affecting bee constancy towards flowers. Particularly in Europe, this aspect was subsequently examined in several studies, among which mention may be made of those by Synge (1947) and Percival (1947) on pollen loads collected from $A$ mellifera bee colonies in the UK; Louveaux (1954, 1958) from France; Maurizio (1949) from Switzerland; Knee and Moeller (1967), and O'Neal and Waller (1984) from the USA. A classic example of the study of pollen loads is that of Hodges (1955), who presented a comprehensive and practical guide to identifying pollen sources in the UK.

Melittopalynological studies on the sources of pollen in Asia have been very few. Systematic investigations have been made of the pollen sources on the Mahabaleshwar plateau in Maharashtra in western India by Deodikar et al (Deodikar, 1965). Routine laboratory studies using melittopalynological methods have been

\footnotetext{
${ }^{*}$ Correspondence and reprints
} 
made at the Central Bee Research and Training Institute, Pune, India, to evaluate sources of pollen and nectar for A cerana Fabr bees in different parts of India (Chandran and Suryanarayana, 1970; Suryanarayana, 1975, 1978; Chaudhari, 1977; Singh et al, 1987; Suryanarayana and Singh, 1989). Sharma (1970 a,b) analysed pollen loads collected from Kangra, Himachal Pradesh; and Chaturvedi (1973, 1977) investigated the pollen sources at Banthra (Lucknow), Uttar Pradesh.

Muzaffarpur $\left(26^{\circ} 07^{\prime} \mathrm{N}, 85^{\circ} 24^{\prime} \mathrm{E}\right)$ is an important area for honey production in $\mathrm{Bi}$ har, northern India. Many beekeepers from distant areas migrate their bee colonies to Muzaffarpur for the honey harvest. In spite of its importance for beekeeping, very little information is available on bee foraging sources in this area. The Central Bee Research and Training Institute, Khadi and
Village Industries Commission, Pune, established a Field Observation Station at Muzaffarpur during 1976 for studies on various aspects of beekeeping. The results of melittopalynological investigations on the sources of pollen are presented here.

\section{MATERIALS AND METHODS}

About 40 colonies of $A$ cerana and 30 colonies of $A$ mellifera have been maintained at the Field Observation Station, Muzaffarpur. The 2 bee species were kept in 2 separate apiaries $2 \mathrm{~km}$ apart during 1987-1988, while during 19881989 , they were kept in the same apiary about 5 $\mathrm{km}$ away from the 2 previous apiaries (fig 1 ). Botanical surveys of the areas around these apiaries have been made and observations were made on the component flowering species, as well as visits of bees to these flowers. Samples of pollen (anthers, flowers and inflorescences) of the flowering species were collected. Refer-

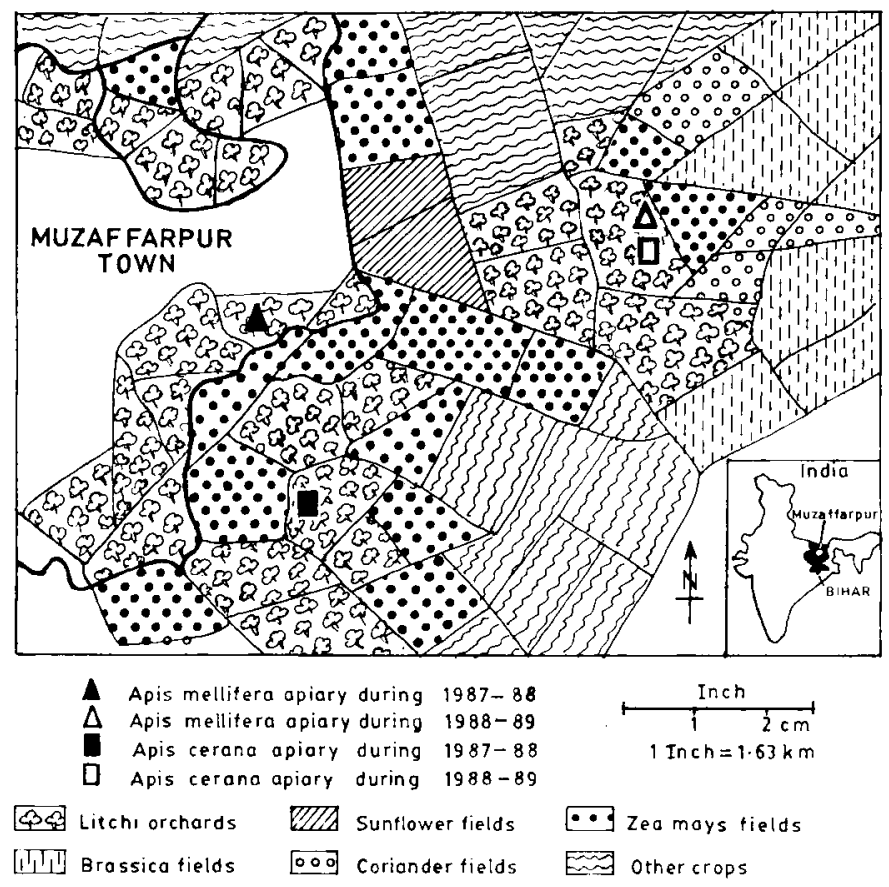

Fig 1. Map of Muzaffarpur area indicating location of apiaries. 
ence slides of pollen were prepared following the methods of Wodehouse (1935) and Erdtman (1952).

Samples of pollen loads brought by forager bees into the colonies were collected throughout the day at hourly intervals. The incoming pollen foragers were caught by hand by holding their wings. The 2 loads on the 2 hind legs were gently removed onto a slip of clean paper; the forager was then let off to resume its activity. The 2 loads were then packed in 2 separate paper packets. Each packet was labelled with data on the colony number, bee species, time and date of collection, colour of the load and number of incoming forager bees per minute with similar type of pollen. This was done at $1-$ 2-hour intervals throughout the day. Sampling was performed once a week. A total of 810 pollen loads from $A$ cerana colonies and 1260 from $A$ mellifera colonies was collected over more than 2 years of study from January 1987 to March 1989. To identify the pollen sources, small amounts of pollen from different parts of each pollen load sample were transferred on to a glass slide by a needle and a temporary mount was made. The mount was examined microscopically for pollen contents. Identification of the pollen species was confirmed by comparing these with the pollen in the reference pollen slides.

\section{RESULTS AND DISCUSSION}

Muzaffarpur is a predominantly agricultural area. The important annual crops during 1987-1989 were Zea mays L, Hordeum vulgare L, Brassica spp, Helianthus annuus L, Sesamum indicum L, Coriandrum sativum L, Trigonella corniculata L, Cajanus cajan ( $L$ ) Millsp, Pisum sativum $L$ var arvense (L) Poir, Vigna $s p$ and different cucurbit species. These contribute to the seasonal bee forage. Nephelium litchi Camb and Mangifera indica $L$ were important fruit crops. Other horticultural crops of minor importance were Psidium guajava $\mathrm{L}$, Citrus spp, Spondias pinnata (Lf) Kurz and Emblica officinalis Gaertn. All these plants provided both nectar and polien, excepting
Emblica officinalis, which is exclusively a source of pollen.

Other pollen and nectar sources were: a), the following arboreal species cultivated or growing wild: Borassus flabellifer $L$, Bombax ceiba L, Cocos nucifera L, Dalbergia sissoo Roxb, Delonix regia (Boj) Raf, Moringa oleifera Lamk, Tamarindus indica L, Wendlandia exserta (Roxb) DC; b), the most important weeds: Cannabis sativa L, Cleome sp, Cyanotis sp, Cosmos bipinnatus Cav, Cyperus sp, and Parthenium hysterophorus $\mathrm{L}$.

From the results it appeared that a total number of 40 species served as pollen sources to $A$ cerana and 48 to $A$ mellifera (table 1). The major pollen sources for A cerana were, in order of importance, Zea mays, Brassica spp, Phoenix sylvestris (L) Roxb and Borassus flabellifer. Zea mays provided $34 \%$ of the total pollen loads and was a dominant source providing pollen almost every month. Cyanotis sp, Cosmos bipinnatus, Fabaceae, Cucurbitaceae and Cocos nucifera were sources of medium importance, providing a significant quantity of pollen.

The major pollen sources for $A$ mellifera were, in order of importance, Zea mays, Parthenium hysterophorus, Brassica spp, Phoenix sylvestris, Borassus flabellifer, Fabaceae, Cucurbitaceae, Cajanus cajan, Pisum sativum var arvense and Cosmos bipinnatus. However, only Zea mays, Fabaceae, Cucurbitaceae and Parthenium hysterophorus provided forage for a major part of the year and the others served as forage sources only for a few months. Other sources which contributed significantly to the total pollen availability, in order of importance, were Coriandrum sativum, Cocos nucifera, Cyanotis sp, Helianthus annuus and Asteraceae.

In table II a floral calendar is provided of plants of significance to beekeeping in Muzaffarpur. Although pollen is available 
Table I. Polien sources of Apis cerana Fabr and $A$ mellifera $L$ at Muzaffarpur, Bihar, India.

\begin{tabular}{|c|c|c|c|c|c|c|c|c|c|c|c|c|}
\hline \multirow[b]{2}{*}{ TAXON } & \multicolumn{12}{|c|}{ MONTHS } \\
\hline & $\mathrm{J}$ & $\mathrm{F}$ & M & A & M & J & $\mathrm{J}$ & A & $\mathrm{s}$ & 0 & $\mathrm{~N}$ & 0 \\
\hline $\begin{array}{l}\text { AMARANTHACEAE } \\
\text { Amaranthus sp. }\end{array}$ & & & $0 \bullet$ & & 0 & 0 & 0 & & & & & \\
\hline $\begin{array}{l}\text { APIACEAE } \\
\text { Coriandrum sativum Linn. }\end{array}$ & 04 & 04 & $\Delta$ & & & & & & & & & \\
\hline $\begin{array}{l}\text { ARECACEAE } \\
\text { Borossus flabelliter Linn. }\end{array}$ & & & & $\square \square$ & a & $\square=$ & & a & $\mathbf{a}$ & a & 0 & \\
\hline Cocos nucitera Linn. & & & & $\Delta \boldsymbol{A}$ & $\Delta$ & $\Delta$ & $\Delta \Delta$ & 4 & $\Delta \boldsymbol{\Delta}$ & 4 & $\Delta \Delta$ & 4 \\
\hline Phoenix sylvestris (Linn.) Roxb. & D田 & Q0 & $\mathbf{a}$ & & & & & & & 口 & $\square$ & a \\
\hline $\begin{array}{l}\text { ASTERACEAE } \\
\text { Ageratum sp. }\end{array}$ & & & & & $\bullet$ & & & & & & & \\
\hline Cosmos bipinnatus cav. & - & & & & & & & & & $\Delta \mathbf{n}$ & $\Delta \boldsymbol{\sigma}$ & $\Delta \pi$ \\
\hline Dahlio pinnata Cav. & & & $\bullet$ & & $\bullet$ & & & & & $\bullet$ & $\bullet$ & \\
\hline Helianthus annuus Linn. & & & & & 4 & $\Delta$ & $\Delta$ & $\mathbf{A}$ & & & & \\
\hline Lagascea mollis Cav. & & & & & & & & & & & $\circ \bullet$ & \\
\hline Parthenium hysterophorus Linn. & & & (1) & (a) & - & - & - & a & & & ! & \\
\hline Taraxacum sp. & & & $\bullet$ & 0 & 0 & & & & & & & \\
\hline $\begin{array}{l}\text { BALSAMINACEAE } \\
\text { Impatiens balsamina Linn. }\end{array}$ & & & & & & & & & & & - & \\
\hline $\begin{array}{l}\text { BOMBACACEAE } \\
\text { Bombax ceiba Linn. }\end{array}$ & & $0 \cdot$ & $0 \bullet$ & & & & & & & & & \\
\hline $\begin{array}{l}\text { BRASSICACEAE } \\
\text { Brassica spp. }\end{array}$ & $\square$ & 0 & च & & & & & & & & an & an \\
\hline Raphanus sativus Linn. & 0 & & & & & & & & & & & \\
\hline $\begin{array}{l}\text { CAESALPINIACEAE } \\
\text { Delonix regia (Boj.) Rafin. }\end{array}$ & & & & 0 & $0 \bullet$ & - & & & & & & \\
\hline Tamarindus indica Linn. & & & & - & & & & & & & & \\
\hline $\begin{array}{l}\text { CANNABACEAE } \\
\text { Cannabis sativa Linn. }\end{array}$ & - & & o. & $0 \cdot$ & 0 & & & & & & & $\bullet$ \\
\hline $\begin{array}{l}\text { CAPPARACEAE } \\
\text { Cleome sp. }\end{array}$ & & & & & & & - & $\bullet$ & $\cdot$ & & & \\
\hline $\begin{array}{l}\text { COMMELINACEAE } \\
\text { Commeling sp. }\end{array}$ & & & & & & $\bullet$ & & & $0 \bullet$ & $0 \bullet$ & 0 & \\
\hline Cyanotis sp. & & & & & & & & & & $\Delta \Delta$ & $\Delta \Delta$ & \\
\hline $\begin{array}{l}\text { CUCURBITACEAE } \\
\text { Cucumis sp. }\end{array}$ & & & & & $0 \bullet$ & $\bullet$ & & - & & 0 & & \\
\hline Cucumis melo Linn. & & & & $\bullet$ & $\bullet$ & & & & & & & \\
\hline Cucumis sativus Linn. & & & - & & $\bullet$ & & & & & $\bullet$ & & - \\
\hline Cucurbita spp. & a & a & a & $\Delta \square$ & $\Delta$ & $\Delta$ & $\Delta \mathrm{D}$ & a & $\Delta \theta$ & $\Delta \mathbf{\square}$ & $\Delta \square$ & $\Delta$ \\
\hline Lufto sp. & & & $\circ \bullet$ & & $\bullet$ & & & & - & & & \\
\hline Momordica charantia Linn. & & & & & 0 & & & & & & & \\
\hline $\begin{array}{l}\text { CYPERACEAE } \\
\text { Cyperus sp. }\end{array}$ & & & & & 0 & & $\bullet$ & 0 & 0 & & & \\
\hline
\end{tabular}

year-round in the area studied, the peak pollen availability was during January-May and in November. During July, August and September it was poor. A maximum number of sources was visited by $A$ cerana in May and in November, while in July and August the number was the lowest. For $A$ mellifera the maximum number was in March, May and November and the lowest was in July and August. Photomicrographs of some poilen sources are given in figure 2.

An analysis of the contribution of anemophilous plant species to pollen availability is given in table III. Out of the 40 sources of pollen for $A$ cerana bees, 13 sources can be considered as anemophilous, and contributed $495(61.7 \%)$ pollen loads. Of these $381(70.7 \%)$ loads were contributed by 3 major sources, viz, Borassus flabelli- 


\begin{tabular}{|c|c|c|c|c|c|c|c|c|c|c|c|c|}
\hline \multirow[b]{2}{*}{ TAXON } & \multicolumn{12}{|c|}{ MONTHS } \\
\hline & J & $\mathrm{F}$ & M & A & $M$ & $J$ & $\mathrm{~J}$ & A & $\mathrm{s}$ & 0 & $\mathrm{~N}$ & D \\
\hline $\begin{array}{l}\text { EUPHORBIACEAE } \\
\text { Croton bonplandianum Baili. }\end{array}$ & & & & & & 0. & 0 & & 0 & 0 & & \\
\hline $\begin{array}{l}\text { FABACEAE } \\
\text { Cajanus cajan (Linn.) Millsp. }\end{array}$ & 00 & 00 & & 10 & 0 & & & & & & & on \\
\hline $\begin{array}{c}\text { Pisum sativum Linn var, arvense. (Linn.) } \\
\text { Poir. }\end{array}$ & $\circ \mathbf{\square}$ & o & $\Delta$ & & & & & & & & & \\
\hline Trigonella corniculata Linn. & $0 \cdot$ & & & & & & & & & & & $\bullet$ \\
\hline $\begin{array}{l}\text { Vigna sp. } \\
\text { LORANTHACEAE }\end{array}$ & & & & - & $0 \cdot 1$ & & & & & & & \\
\hline $\begin{array}{l}\text { LORANTHACEAE } \\
\text { Dendrophthoe folcato (Linn. F.) Ettingsh. }\end{array}$ & & & & & & & & & & o & 10 & \\
\hline $\begin{array}{l}\text { MIMOSACEAE } \\
\text { Mimosa sp. }\end{array}$ & & & & & & 0 & & & & & & \\
\hline $\begin{array}{l}\text { MORINGACEAE } \\
\text { Moringa oleifera Lomk. }\end{array}$ & & & & & & 0 & & & & & 0 & 0 \\
\hline $\begin{array}{l}\text { MYRTACEAE } \\
\text { Psidium guajara Linn. }\end{array}$ & & & & 0 & 0 & & $\bullet$ & & & & - & \\
\hline $\begin{array}{l}\text { PEDALIACEAE } \\
\text { Sesamum in dicum Linn. }\end{array}$ & & & & & & & & & & - & & \\
\hline $\begin{array}{l}\text { POACEAE } \\
\text { Hordeum sp. }\end{array}$ & & & & & & & & & & o• & $0 \bullet$ & \\
\hline Jowar type & & & 0 & & & & & & & & $\circ \bullet$ & \\
\hline Zea mays Linn. & Q & an & av & av & प0 & Q0 & Q & 0 & Q & $\square \pi$ & $a$ & $\square$ \\
\hline $\begin{array}{l}\text { SAPINDACEAE } \\
\text { Nephelium litchi Cambess. }\end{array}$ & & & $\circ \cdot$ & & & & & & & & & \\
\hline AMARYLLIOACEAE (Unidentified) & & & & & & $\bullet$ & $0 \bullet$ & & & 0 & & \\
\hline ARECACEAE (Unidentified) & & & & & & & & & & & 0 & \\
\hline ASTERACEAE (Unidentified) & $\Delta$ & & $\Delta$ & & & & & & & $\Delta$ & 04 & 01 \\
\hline CAESALPINIACEAE (Unidentified) & & & $\bullet$ & & & & & & $\bullet$ & $\bullet$ & & \\
\hline CUCURBITACEAE (Unidentified) & $\bullet$ & & $\bullet$ & & & $\cdot$ & & $\bullet$ & & $\bullet$ & & \\
\hline EUPHORBIACEAE (Unidentified) & & & & & $0 \bullet$ & & & & & & & \\
\hline FABACEAE (Unidentified) & $\Delta \mathbf{a}$ & $\Delta \mathbf{a}$ & $\Delta \mathbf{0}$ & $\Delta \mathbf{D}$ & & $\square$ & & 口 & $\mathbf{D}$ & $\Delta \mathbf{D}$ & $\Delta \mathbf{a}$ & $\Delta \mathbf{a}$ \\
\hline MALVACEAE (Unidentified) & & & & & & & & & $\bullet$ & & & \\
\hline POACEAE (Unidentified) & & & $0 \bullet$ & & $\circ \circ$ & & & & & & $0 \bullet$ & \\
\hline RUTACEAE (Unidentified) & & & $0 \bullet$ & & $\bullet$ & $\bullet$ & $\bullet$ & $\bullet$ & 0 & & & \\
\hline SAPINDACEAE (Unidentitied) & & & & & & & & & & $\bullet$ & $\bullet$ & $\bullet$ \\
\hline TILIACEAE & & & $\bullet$ & & & & & $\bullet$ & & & 0 & \\
\hline A. cerana & ellif & era & & & & & & & & of 10 & oads & \\
\hline $0=$ Minor & Min & & & & & & & & $1-20$ & & Ainor & \\
\hline$\Delta=$ Medium & Med & ium & & & & & & & $21-5$ & & Mediun & \\
\hline$\square=$ Major & Maj & & & & & & & & $>5$ & $50 \mathrm{M}$ & Aajor & \\
\hline
\end{tabular}

fer, Phoenix sylvestris and Zea mays. In the case of $A$ mellifera also, 13 anemophilous species, out of the total number of 48 pollen sources contributed 569 (45.2\%) pollen loads. Of these, 4 major sources of pollen, viz, Borassus flabellifer, Phoenix sylvestris, Parthenium hysterophorus and Zea mays, contributed 481 (84.5\%) loads. For both honey bee species, anemophilous plant species constituted important pollen sources at Muzaffarpur. Sharma (1970a) reported a similar predominance of anemophilous sources of pollen in Kangra, Himachal Pradesh, while in the Shimla hills of the same state, Sharma (1983) recorded only one (Artemisia $\mathrm{sp}$ ) important pollen source, which was anemophilous. Zea mays was recorded as the most important source in southern Wisconsin, USA, by Knee and Moeller (1967), while 
Table II. Floral calendar of sources of bee forage to honey bees in the Muzaffarpur area (Bihar, india).

\begin{tabular}{|c|c|c|c|}
\hline Taxon & Family & Flowering period & $\begin{array}{l}\text { Bee forage } \\
\text { value * }\end{array}$ \\
\hline Zea mays Linn & Poaceae & January to December & P3 \\
\hline Cucurbita sp & Cucurbitaceae & January to December & P3 \\
\hline Fabaceae & Fabaceae & $\begin{array}{l}\text { January to April, June, } \\
\text { August to December }\end{array}$ & P3 \\
\hline Cannabis sativa Linn & Cannabaceae & January to May, December & P1 \\
\hline Phoenix sylvestris (Linn) Roxb & Arecaeae & $\begin{array}{l}\text { January to March, } \\
\text { October to December }\end{array}$ & P3 \\
\hline Cucurbitaceae & Cucurbitaceae & $\begin{array}{l}\text { January, March, June } \\
\text { August, October }\end{array}$ & P1 \\
\hline Brassica sp & Brassicaceae & $\begin{array}{l}\text { January to March, } \\
\text { November, December }\end{array}$ & P3 N3 \\
\hline Cajanus cajan (Linn) Millsp & Fabaceae & $\begin{array}{l}\text { January, February, April, } \\
\text { May, December }\end{array}$ & $\mathrm{P} 2 \mathrm{~N} 1$ \\
\hline Asteraceae & Asteraceae & $\begin{array}{l}\text { January, March, } \\
\text { October to December }\end{array}$ & $\mathrm{P} 1$ \\
\hline Cosmos bipinnatus Cav & Asteraceae & January, October to December & $\mathrm{P} 2$ \\
\hline $\begin{array}{l}\text { Pisum sativum Linn } \\
\text { var arvense (Linn) Poir }\end{array}$ & Fabaceae & January to March & $\mathrm{P} 2$ \\
\hline Coriandrum sativum Linn & Apiaceae & January to March & P2 N2 \\
\hline Trigonella corniculata Linn & Fabaceae & January, December & P1 N1 \\
\hline Rutaceae & Rutaceae & $\begin{array}{l}\text { February, March, } \\
\text { May to September }\end{array}$ & P1 \\
\hline Bombax ceiba Linn & Bombacaceae & February, March & P1 N1 \\
\hline Mangifera indica Linn & Anacardiaceae & February, March & N1 \\
\hline Parthenium hysterophorus Linn & Asteraceae & March to August, November & P3 \\
\hline Croton bonplandianum Baill & Euphorbiaceae & $\begin{array}{l}\text { March, June, July, } \\
\text { September, October }\end{array}$ & $\mathrm{P} 1$ \\
\hline Amaranthus sp & Amaranthaceae & March, May to July & $\mathrm{P} 1$ \\
\hline Dahlia pinnata Cav & Asteraceae & $\begin{array}{l}\text { March, May, October, } \\
\text { November }\end{array}$ & P1 \\
\hline Cucumis sativus Linn & Cucurbitaceae & $\begin{array}{l}\text { March, May, October, } \\
\text { December }\end{array}$ & P1 \\
\hline Taraxacum sp & Asteraceae & March to May & P1 \\
\hline Luffa sp & Cucurbitaceae & March, May, September & P1 \\
\hline Poaceae & Poaceae & March, May, November & P1 \\
\hline
\end{tabular}




\begin{tabular}{|c|c|c|c|}
\hline Caesalpiniaceae & Caesalpiniaceae & March, September, October & P1 \\
\hline Dalbergia sissoo Roxb & Fabaceae & March, April & N1 \\
\hline Sorghum type & Poaceae & March, Novernber & P1 \\
\hline Nephelium litchi Camb & Sapindaceae & March & P1 N3 \\
\hline Emblica officinalis Gaertn & Euphorbiaceae & March & $\mathrm{P} 2$ \\
\hline Spondias pinnata (Linn f) Kurz & Anacardiaceae & March & N2 \\
\hline Cccos nucifera Linn & Arecaceae & April to December & P2 \\
\hline Borassus flabellifer Linn & Arecaceae & August to November & \\
\hline Psidium guajava Linn & Myrtaceae & April, May, July, November & P1 N1 \\
\hline Delonix regia (Boj) Rafin & Caesalpiniaceae & April to June & $\mathrm{P} 1$ \\
\hline Cucumis melo Linn & Cucurbitaceae & April to June & P1 \\
\hline Vignasp & Fabaceae & April, May & N2 \\
\hline Wendlandia exserta (Roxb) DC & Rubiaceae & April, May & N2 \\
\hline Tamarindus indica Linn & Caesalpiniaceae & April, May & P1 N1 \\
\hline Helianthus annuus Linn & Asteraceae & May to August & P2 N1 \\
\hline Cyperus sp & Cyperaceae & May, July to September & P1 \\
\hline Cucumis sp & Cucurbitaceae & May, June, August, October & P1 \\
\hline Ageratum sp & Asteraceae & May & P1 \\
\hline Euphorbiaceae & Euphorbiaceae & May & P1 \\
\hline Momordica charantia Linn & Cucurbitaceae & May & P1 \\
\hline Commelina sp & Commelinaceae & June, August to November & P1 \\
\hline Amaryllidaceae & Amaryllidaceae & June, July, October & $P 1$ \\
\hline Cleomesp & Capparaceae & July to September & $\mathrm{P} 1$ \\
\hline Moringa oleifera Lamk & Moringaceae & June, November, December & P1 N1 \\
\hline Mimosa sp & Mimosaceae & June & P1 \\
\hline Malvaceae & Malvaceae & September & P1 \\
\hline Sapindaceae & Sapindaceae & October to December & P1 N1 \\
\hline Cyanotis sp & Commelinaceae & October, November & $\mathrm{P} 2$ \\
\hline $\begin{array}{l}\text { Dendrophthoe falcata (Linn f) } \\
\text { Ettingsh }\end{array}$ & Loranthaceae & October, November & P1 \\
\hline Hordeum sp & Poaceae & October, November & P1 \\
\hline Sesamum indicum Linn & Pedaliaceae & October & P1 N1 \\
\hline Impatiens balsamina Linn & Balsaminaceae & November & P1 N1 \\
\hline Arecaceae & Arecaceae & November & P1 \\
\hline Lagascea mollis Cav & Asteraceae & November & P1 \\
\hline
\end{tabular}

* Bee forage value: $P=$ Pollen; $N$ = Nectar. Relative importance as assessed visually and palynologically: $1=$ Minor; 2 = Medium; 3 = Major. 

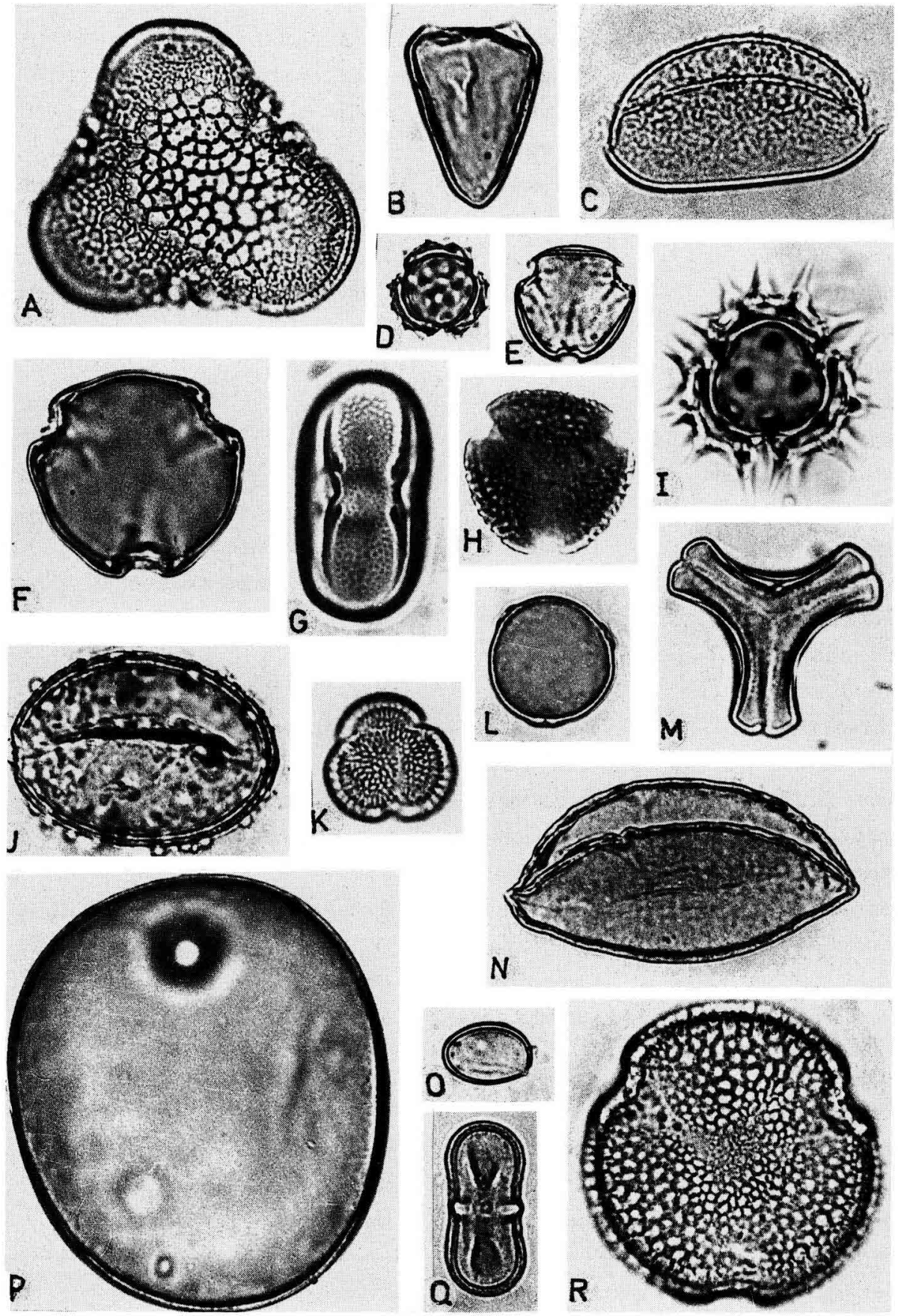
Table III. Details of the pollen loads from anemophilous plant species collected by honey bees in Muzaffarpur, Bihar, during 1987-1989.

\begin{tabular}{|c|c|c|c|c|c|c|}
\hline \multirow{3}{*}{$\begin{array}{l}\text { Plant species } \\
\text { or family }\end{array}$} & \multicolumn{6}{|c|}{ No of pollen loads * } \\
\hline & \multicolumn{3}{|c|}{ Apis cerana } & \multicolumn{3}{|c|}{ Apis mellifera } \\
\hline & Major & Medium & Minor & Major & Medium & Minor \\
\hline Ageratum sp & - & - & - & - & - & $\begin{array}{c}1 \\
(0.18)\end{array}$ \\
\hline Amaranthus sp & - & - & $\begin{array}{c}17 \\
(3.43)\end{array}$ & - & - & $\begin{array}{c}1 \\
(0.18)\end{array}$ \\
\hline Borassus flabellifer & $\begin{array}{c}51 \\
(10.30)\end{array}$ & - & - & $\begin{array}{c}71 \\
(12.48)\end{array}$ & - & - \\
\hline Cannabis sativa & - & - & $\begin{array}{c}12 \\
(2.42)\end{array}$ & - & - & $\begin{array}{c}13 \\
(2.29)\end{array}$ \\
\hline Cocos nucifera & - & $\begin{array}{c}21 \\
(4.24)\end{array}$ & - & - & $\begin{array}{c}29 \\
(5.10)\end{array}$ & - \\
\hline Croton bonplandianum & - & - & $\begin{array}{c}12 \\
(2.42)\end{array}$ & - & - & $\begin{array}{c}3 \\
(0.53)\end{array}$ \\
\hline Cyperus sp & - & - & $\begin{array}{c}9 \\
(1.82)\end{array}$ & - & - & $\begin{array}{c}1 \\
(0.18)\end{array}$ \\
\hline Hordeum sp & - & - & $\begin{array}{c}20 \\
(4.04)\end{array}$ & - & - & $\begin{array}{c}14 \\
(2.46)\end{array}$ \\
\hline Mimosa sp & - & - & $\begin{array}{c}1 \\
(0.20)\end{array}$ & - & - & - \\
\hline Parthenium hysterophorus & - & - & - & $\begin{array}{c}122 \\
(21.44)\end{array}$ & - & - \\
\hline Phoenix sylvestris & $\begin{array}{c}55 \\
(11.11)\end{array}$ & - & - & $\begin{array}{c}73 \\
(12.83)\end{array}$ & - & - \\
\hline Sorghum type & - & - & $\begin{array}{c}7 \\
(1.41)\end{array}$ & - & - & $\begin{array}{c}6 \\
(1.05)\end{array}$ \\
\hline Zea mays & $\begin{array}{c}275 \\
(55.56)\end{array}$ & - & - & $\begin{array}{c}215 \\
(37.79)\end{array}$ & - & - \\
\hline Arecaceae & - & - & $\begin{array}{c}1 \\
(0.20)\end{array}$ & - & - & - \\
\hline Poaceae & - & - & $\begin{array}{c}14 \\
(2.83)\end{array}$ & - & - & $\begin{array}{c}20 \\
(3.52)\end{array}$ \\
\hline Total & $\begin{array}{c}381 \\
(76.97)\end{array}$ & $\begin{array}{c}21 \\
(4.24)\end{array}$ & $\begin{array}{c}93 \\
(18.79)\end{array}$ & $\begin{array}{c}481 \\
(84.53)\end{array}$ & $\begin{array}{c}29 \\
(5.10)\end{array}$ & $\begin{array}{c}59 \\
(10.37)\end{array}$ \\
\hline
\end{tabular}

* Figures in parentheses are percentages of total anemophilous pollen (ie, 495 loads of Apis cerana and 569 loads of Apis mellifera).

Fig 2. A-R. Photomicrographs of pollen grains $(x 650)$ of some bee plants at Muzaffarpur, Bihar, India. (A) Bombax ceiba Linn. (B) Cyperus sp. (C) Cyanotis sp. (D) Parthenium hysterophorus Linn. (E) Nephelium litchi Camb. (F) Moringa oleifera Lamk. (G) Pisum sp. (H) Cajanus cajan (Linn) Millsp. (I) Cosmos sp. (J) Borassus flabellifer Linn. (K) Brassica sp. (L) Cannabis sativa Linn. (M) Dendrophthoe sp. (N) Cocos nucifera Linn. (O) Phoenix sylvestris (Linn) Roxb. (P) Zea mays Linn. (Q) Coriandrum sativum Linn. (R) Cucurbita maxima Duchesne. 
wind-pollinated species contributed to an unexpectedly large amount of pollen in the LaCrosse county, Wisconsin, USA (Severson and Parry, 1981). Todd and Bretherick (1942), while giving the chemical composition of pollen in 32 plant species, observed that pollen from anemophilous plants was not greatly different from pollens of entomophilous plants in their protein value. Maurizio (1960) classified corn pollen under the group of highly nutritive pollens. Dietz (1975) mentioned that the difference between insect-pollinated and windpollinated plants in protein content of pollen was non-significant. It is generally observed that brood rearing activity in the colonies is vigorous during the period when maize pollen is available (personal observations). It therefore appears that anemophily as a concept of pollination ecology is not relevant in the case of social insects like honey bees, whose foraging behaviour is controlled by a different set of factors.

The period and abundance of the main pollen sources of $A$ cerana and $A$ mellifera have been shown in figures 3 and 4 respectively.

Important differences were found in the pollen sources between $A$ cerana and $A$ mellifera. These are given below: a) pollen load samples of $A$ cerana did not have even a single load of Parthenium hysterophorus. This was noted as the second most important pollen source for $A$ mellifera. Suryanarayana and Singh (1989) recorded earlier that $A$ cerana did not forage on $P$ hysterophorus, although this was a common weed in the area. b) Samples of A mellifera pollen loads did not represent Dendrophthoe falcata (Lf) Ettingsh and Moringa oleifera, which were sources for A cerana. This might be due to competition among the floral sources and their relative unattractiveness to $A$ mellifera. c) Cajanus cajan and Pisum sativum var arvense were important forage sources for A mellifera, whereas these were only of minor importance for $A$ cerana. This difference in foraging behaviour is significant from the point of view of pollination of these crops. d) Helianthus annuus was an important

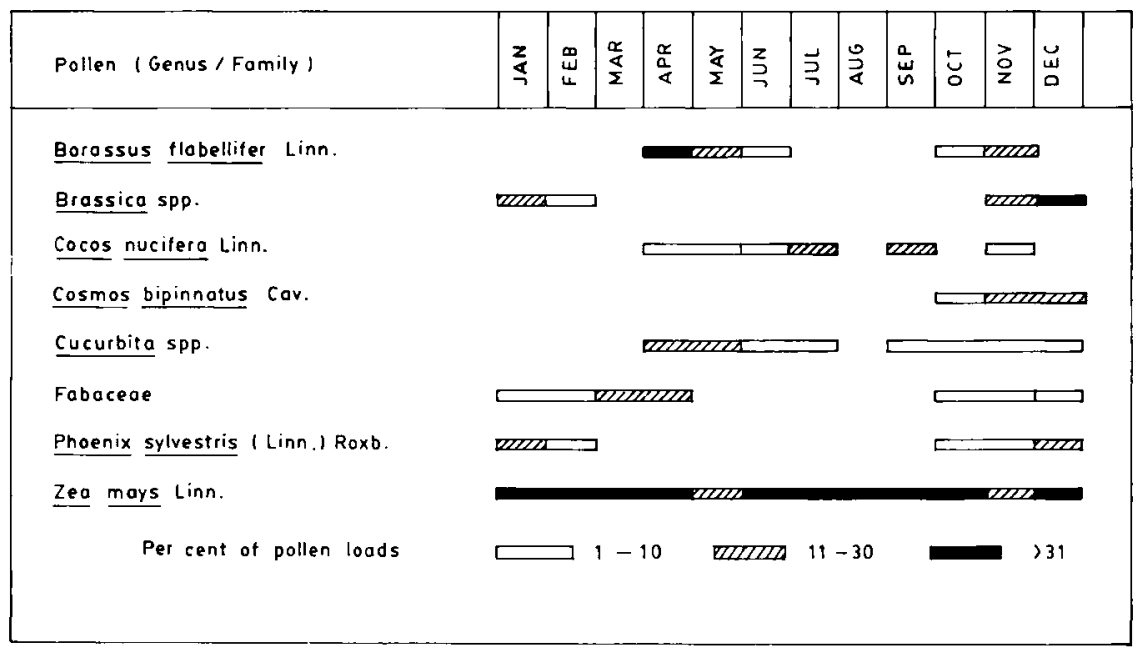

Fig 3. Monthly distribution of major sources of pollen to Apis cerana Fabr at Muzaffarpur, Bihar, India, during 1987-1988. 


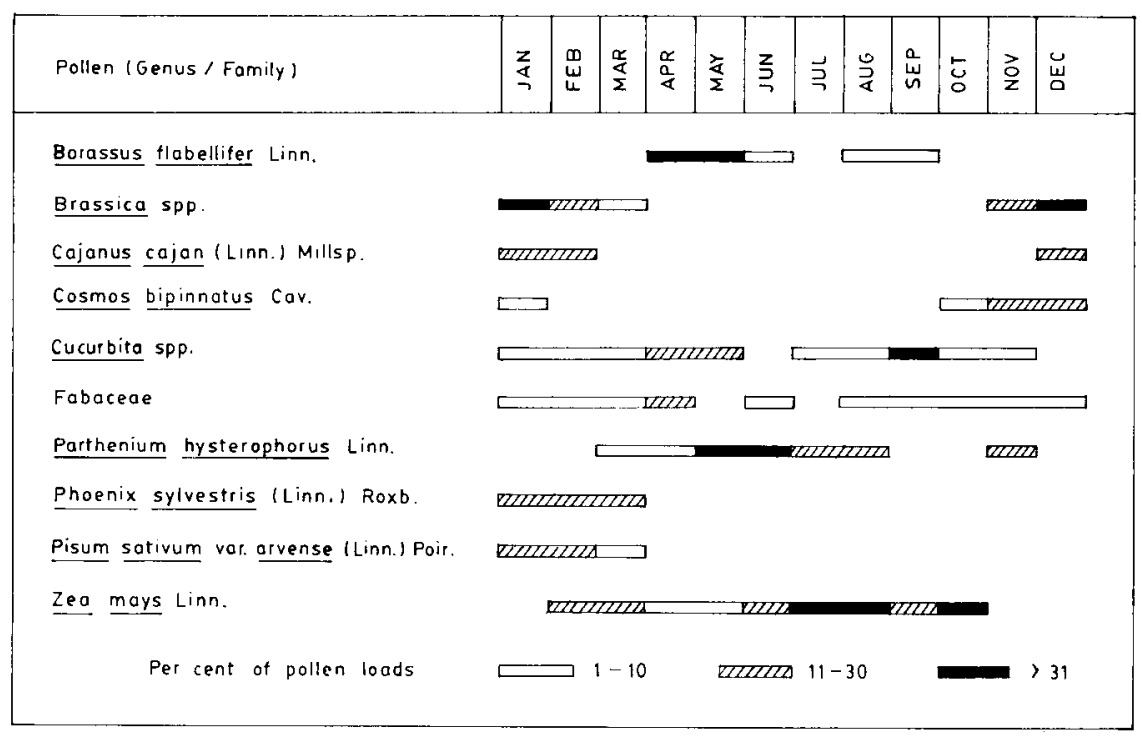

Fig 4. Monthly distribution of major sources of pollen to Apis mellifera $L$ at Muzaffarpur, Bihar, India, during 1987-1988.

source for $A$ mellifera, but it was not represented in the loads brought by A cerana. This might be due to non-availability of sunflower within the flight range of $A$ cerana, which has been reported as 700 to 900 m (Naim and Phadke, 1972; Darade et al, 1989). Suryanarayana et al (1987) showed that $A$ cerana was one of the important pollinators of sunflower in Maharashtra.

It is interesting to note that Zea mays was an important pollen source for both $A$ cerana and $A$ mellifera in agricultural areas such as Muzaffarpur, as has been observed in several parts of the world (for example, Sladen (1911) in England; Casteel (1912), Knee and Moeller (1967), and Severson and Parry (1981) in the USA and Maurizio (1953) in Switzerland). In India maize has been found to be a source of pollen for $A$ cerana bees in the Punjab
(Chaudhari, 1977) and in Andhra Pradesh (Singh et al, 1987).

Though Nephelium litchi is an important nectar source (Phadke and Naim, 1974; Suryanarayana et al, 1981; Rao, 1983), it was found to be a poor pollen source. Likewise, Mangifera indica and Wendlandia exserta, which were reported to be nectar sources (Rao and Nair, 1985; and personal observations), were not pollen sources.

Out of the 810 pollen loads of $A$ cerana examined, only one pollen load had a bifloral source and all the rest were unifloral. The bifloral load was collected in November from Phoenix sylvestris and Zea mays. $A$ mellifera also collected one bifloral pollen load in November from Cucurbitaceae and Cocos nucifera. Bifloral loads were likewise found to be rare in the pollen 
loads collected by $A$ cerana in Vijayarai, Andhra Pradesh (Singh et al, 1987). However, Sharma $(1970 a, b)$ found that 8 pollen loads out of 19 collected during 1st June to 9th July, 1968 at Kangra, Himachal Pradesh, were mixed; one had 4 pollen species, 2 had 3 pollen species and 5 were bifloral, while only one out of $27 \mathrm{col}-$ lected during September, 1968 was mixed with 3 pollen species. She therefore concluded that June-July was the dearth period in Kangra and that bees were therefore forced to collect pollen from more than one source on several of their foraging trips. On the other hand, at Banthra (Lucknow), Uttar Pradesh, she found that 3 out of 49 loads collected in February, 1970 and 3 out of 44 loads collected in April, 1970 were bifloral (Chaturvedi, 1973).

The almost exclusive occurrence of unifloral loads in the present investigations is indicative of the richness of the local pollen resources to the honey bees.

\section{ACKNOWLEDGMENTS}

Thanks are due to the field staff of the Beekeeping Observation Station, Muzaffarpur for their active help in the collection of pollen loads and plant specimens during the period of observation. The authors thank the referees of the paper for their comments and valuable suggestions.

\footnotetext{
Résumé - Étude sur les sources de pollen pour Apis cerana Fabr et Apis mellifera $L$ à Muzaffarpur, Bihar (Inde). Muzaffarpur, dans le Bihar (Inde du Nord), est une région principalement agricole. Les cultures constituent les principales sources de pollen et de nectar pour les abeilles. Au laboratoire de terrain du Central Bee Research and Training Institute à Muzaffarpur, les pelotes de pollen rapportées par les butineuses en 1987-1988 ont été étudiées afin de déterminer l'origine
}

des pollens. Les pelotes ont été échantillonnées toutes les heures durant une journée entière, une fois par semaine. On a récolté environ 810 pelotes de pollen provenant de 40 colonies d' $A$ cerana et 1260 venant de 30 colonies d'A mellifera. En 1987-1988, les colonies des 2 espèces étaient réparties en 2 ruchers distants de $2 \mathrm{~km}$, en 1988-1989 elles étaient regroupées en un même rucher (fig 1).

Au total, 40 espèces de plantes ont fourni du pollen à $A$ mellifera et 48 à $A$ cerana. Les sources polliniques les plus importantes pour A cerana sont : Zea mays $\mathrm{L}$, Brassica spp, Phoenix sylvestris ( $L$ ) Roxb et Borassus flabellifer L. À celles-ci il faut ajouter, pour $A$ mellifera, les espèces suivantes : Parthenium hysterophorus L, Cajanus cajan (L) Millsp, Pisum sativum $L$ var arvense (L) Poir et les Cucurbitacées (tableau I). Dans la région de Muzaffarpur, du pollen est disponible toute l'année. C'est de janvier à mai et en novembre qu'il est le plus abondant; de juillet à septembre, la disponibilité est faible (tableau II). Treize plantes anémophiles $(61,7 \%$ des pelotes d'A cerana et $45,2 \%$ des pelotes d'A mellifera) constituent des sources de pollen importantes pour les 2 espèces d'abeilles (tableau III). Parthenium hysterophorus représente la $2^{\mathrm{e}}$ source de pollen pour $A$ mellifera, tandis qu' $A$ cerana n'en a pas récolté une seule pelote. Les grains de pollen de Dendrophthoe falcata (Lf) Ettingsh et de Moringa oleifera Lamk, présents dans les pelotes d'A cerana, n'ont pas été trouvés dans celles d'A mellifera. Nephelium litchi Camb, principale source de nectar à Muzaffarpur, fournit peu de pollen aux abeilles. II n'a été trouvé qu'une seule pelote mixte (2 espèces) dans les échantillons des 2 espèces d'abeilles. Ceci prouve la richesse des plantes locales quant à la fourniture de pollen pour ces insectes.

Apis mellifera / Apis cerana / plante pollinifère / Inde / butinage 
Zusammenfassung - Studien über die Pollenquellen von Apis cerana Fabr und Apis mellifera $\mathrm{L}$ in Muzaffarpur, Bihar (Indien). Muzaffarpur, Bihar, in Nordindien ist überwiegend ein landwirtschaftlich genutztes Gebiet. Kultivierte Nutzpflanzen sind die Hautpollenpflanzen und Nektarpflanzen für die Bienen. An den Völkern von Apis cerana und $A$ mellifera der Feldstation des Zentralen Bienenforschungsinstitutes in Muzaffarpur wurden an den Pollenladungen der heimkehrenden Bienen 1987-1988 Untersuchungen über die Herkunft des Pollens vorgenommen. Ein Mal wöchentlich wurden den ganzen Tag über in stündlichen Abständen Pollenproben gesammelt. Etwa von 40 Völkern von $A$ cerana und von 30 Völkern von $A$ mellifera wurden insgesamt 810 Pollenhöschen von ersterer und 1260 Pollenhöschen von letzterer entnommen. 1987-1988 wurden die beiden Bienenarten auf zwei getrennten Bienenständen 2 $\mathrm{km}$ voneinander entfernt gehalten, 19881989 aber gemeinsam auf einem Bienenstand (Abb 1). Insgesamt 40 Pflanzenarten lieferten Pollen für $A$ cerana und 48 Arten für $A$ mellifera. Die wichtigsten Pollenpflanzen für $A$ cerana waren Zea mais L, Brassica spp, Phoenix silvestris $L$ und Borassus flabellifer L. Zusätzlich zu diesen dienten für Apis mellifera noch Parthenium hysterophorus L, Cajanus cajan L, Pisum sativum $L$ var arvense $L$ Poir und Cucurbitaceen als wichtige Pollenquellen (Tab I). In Muzaffarpur ist für die Bienen Pollen das ganze Jahr über vorhanden. Das Hauptangebot an Pollen lag zwischen Januar und Mai und im November. Von Juli bis September ist das Pollenangebot knapp (Tab II). Dreizehn windblütige Pflanzenarten $61.7 \%$ der Pollenladungen von $A$ cerana und $45.2 \%$ von $A$ mellifera) bildeten für beide Arten wichtige Pollenspender (Tab III). Parthenium hysterophorus war der zweitwichtigste Pollenspender für $A$ mellifera; aber $A$ cerana sammelte von dieser Art nicht einmal eine einzige Ladung. Die Pollenkörner von Dendrophthoe falcata (Lf) Ettingsh und von Moringa oleifera Lamk, die in den Proben von $A$ cerana-Völkern vorhanden waren, wurden in den Proben von $A$ mellifera-Völkern nicht gefunden. Nephelium litchi Camb, die Hauptnektarquelle in Muzaffarpur, erwies sich als wenig ergiebige Pollenquelle. Es wurde bei jeder der beiden Bienenarten nur je ein einziges gemischtes Pollenhöschen (von zwei Pflanzenarten) gefunden. Das beweist die Reichhaltigkeit der lokalen Pollenpflanzen für die Versorgung der Bienenvölker.

\section{Apis mellifera / Apis cerana / Pollen- pflanze / Indien / Trachtverhalten}

\section{REFERENCES}

Betts AD (1935) The constancy of the pollencollecting bee. Bee World 16, 111-113

Casteel DB (1912) The behavior of the honey bee in pollen collecting. US Bur Entomol Bull No 21

Chandran K, Suryanarayana MC (1970) A note on entomophily in Dendrophthoe falcata, and its usefulness to the Indian honeybee. J Apic Res 9, 45-47

Chaturvedi M (1973) An analysis of honeybee pollen loads from Banthra, Lucknow, India. Grana 13, 139-144

Chaturvedi M (1977) Further investigation on the pollen analysis of bees loads from Banthra, India. New Bot 4, 41-47

Chaudhari RK (1977) Forage in Punjab plains (India). Pathankot and adjacent villages. Indian Bee J 39, 15-20

Darade MN, Singh BP, Chakrawarty $P$ (1989) Flight range of Apis cerana. Indian Bee J 51, 59-61

Deodikar GB (1965) Melitto-palynology. Indian Bee J 27, 59-72

Dietz A (1975) Nutrition of the adult honey bee. In: The Hive and the Honey Bee. Dadant and Sons, Hamilton, IL 
Erdtman G (1952) Pollen Morphology and Plant Taxonomy-Angiosperms. Almquist and Wiksells, Uppsala

Hodges D (1955) Pollen loads, the way the worker bee gathers, packs and stores them for use. Am Bee J 95, 475-482

Knee WJ, Moeller FE (1967) Comparative study of pollen sources of honeybees and bumble bees. J Apic Res 6, 133-138

Louveaux J (1954) Études sur la récolte du polIen par les abeilles. XV Int Beekeep Congr, Copenhagen

Louveaux J (1958) Recherches sur la récolte du pollen par les abeilles (Apis mellifica L). Ann Abeille 1, 113-188, 197-221

Maurizio A (1949) Pollenanalytische Untersuchungen an Honig und Pollenhöschen. Beih Schweiz Bienenztg 2, 320-455

Maurizio A (1953) Weitere Untersuchungen an Pollenhöschen. Beih Schweiz Bienenztg 2, 486-556

Maurizio A (1960) Bienenbotanik. In: Biene und Bienenzucht (Büdel A, Herold E, eds) Ehrenwith Verlag, Munich

Naim M, Phadke KG (1972) Flight range of Apis cerana indica when enticed to a feeding dish. J Apic Res 11, 167-169

O'Neal RJ, Waller GD (1984) On the pollen harvest by the honey bee (Apis mellifera $\mathrm{L}$ ) near Tucson, Arizona (1976-1981). Desert Plants 6, 81-94, 99-109 (AA 558/1986)

Percival M (1947) Pollen collection by Apis mellifera. New Phytol 46, 142-173

Phadke KG, Naim M (1974) Observations on the honeybee visitation to the litchi (Nephelium litchi) blossoms at Pusa (Bihar, India). Indian Bee J 36, 9-12

Rao GM (1983) Litchi and bee-keeping. Indian Hortic 28 (2), 19-20

Rao GM, Nair KS (1985) Mango tree - a source of bee forage. Indian Bee J 47, 49-50

Severson DW, Parry JE (1981) A chronology of pollen collection by honeybees. I Apic Res $20,97-103$
Sharma M (1970a) An analysis of pollen loads of honey bees from Kangra, India. Grana 10, 35-42

Sharma M (1970b) Studies on the pollen loads of honeybees from Kangra, India. I Palynol $6,104-110$

Sharma N (1983) Melissopalynology and survey of honey plants in Simla Hills (Himachal Pradesh). MPhil Project Report, Himachal Pradesh University, India (AA 1245/85)

Singh TSMS, Joshi MA, Suryanarayana MC (1987) Evaluation of sources of pollen to honey bees at Vijayarai (Andhra Pradesh). Proc 5th All India Symp Palynol, Nagpur, India, 65-71

Sladen FWL (1911) How pollen is collected by the social bees and the part played in the process by the auricle. Br Bee $J 39,491$ 506

Suryanarayana MC (1975) Studies on bee botany and palynology of the flora and coorg and adjacent parts of the Mysore State. Ph D thesis, Poona University

Suryanarayana MC (1978) Bee plants of India. 1. Carvia callosa (Nees) Brem. Indian Bee J $40,7-10$

Suryanarayana MC, Singh TSMS (1989) Parthenium hysterophorus - a pollen source to Apis mellifera. Bee World 70, 127-129

Suryanarayana MC, Rao GM, Phadke RP (1987) Higher yields of sunflower through honey bees. Indian Fmg 37 (2), 5-7, 19

Suryanarayana MC, Seethalakshmi TS, Phadke RP (1981) Pollen analysis of Indian honeys 1. Honeys from litchi (Nephelium litchi) and Jamun (Syzygium cumini). Proc IV Int Palynol Conf, Lucknow 1976-1977, 3, 491498

Synge AD (1947) Pollen collection by honey bees. J Anim Ecol 16, 122-138

Todd FE, Bretherick O (1942) The composition of pollens. J Econ Entomol 35, 312-317

Wodehouse RP (1935) Pollen Grains. McGraw Hill, New York 